\title{
Spend Now Or Spend Later: The Role Of A Business Education And Critical Thinking Skills In Increasing Retirement Plan Saving Rates For New, Young Enrollees
}

\author{
Priscilla A. Arling, Butler University, USA \\ Jill Kirby, Butler University, USA \\ Kegan Saajasto, Butler University, USA
}

\begin{abstract}
For college graduates entering the workforce, contributing to an employer-sponsored 401(k) retirement plan can be an important way of saving for the future. However, contribution rates for young people in these plans are far below recommended percentages, leading to concerns about future financial stability for these individuals. Prior work has shown that a college student's major and academic coursework affect their general financial knowledge. However, little is known about what content within a course of study correlates with specific financial decisions. The decision of how much to save in a $401(\mathrm{k})$ plan is complex and requires thinking beyond a present-day bias. The ability to think about future, complex problems is often referred to as critical thinking skills. This study is among the first to consider the impact of both college major and critical thinking skills on chosen 401(k) saving rates of young people about to enter the workforce. We presented a hypothetical $401(\mathrm{k})$ plan enrollment scenario to 334 university upperclassmen in order to determine the impact of educational factors on elected saving rates. We found that saving contribution rates increase when individuals are exposed to financial decisionmaking information that is consistent, frequent, and ongoing, such as the learning experienced in a four-year business degree program. We also found that critical thinking skills were independently related to increased contribution rates, regardless of major. Students from both business and non-business majors were able to apply critical thinking skills to a financial planning scenario. The results suggest that development of critical thinking skills and repeated exposure to analysis of financial data would increase 401(k) saving rates and thereby benefit all students in terms of their future financial well-being.
\end{abstract}

Keywords: Critical Thinking; Financial Education; Retirement Plan; Saving

\section{INTRODUCTION}

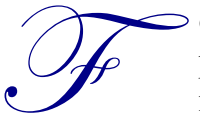
or college students entering their first job post-graduation, retirement planning may not be a high priority. Yet early, consistent, and long-term saving is one of the key factors in building a comfortable retirement nest egg. To assist employees with saving for retirement, companies frequently offer the opportunity to participate in 401(k) retirement plans. Money saved and invested in these plans is not taxed until it is withdrawn, and many employers further incentivize saving in these plans by matching, up to a specified percent, the amount that an employee invests.

Even with tax advantages and other incentives for participation, $21 \%$ of workers whose companies offer 401(k) retirement plans choose not to enroll (Munnell, 2012). Even when individuals do participate, the average contribution rate is between 5\% and 7\% of salary, (American Benefits Council, 2013), while the ideal percentage is close to $15 \%$ (Clark, 2013). Low rates of participation and saving in these plans have been particularly problematic 
for young Americans. In a recent study, 55\% of the young adults surveyed reported that they were not saving in either an individual retirement account (IRA) or a 401(k) account (Lusardi, Mitchell, \& Curto, 2010). Since 2007, the median balance in $401(\mathrm{k})$ and individual retirement accounts (IRAs) has remained roughly the same $(\$ 120,000)$ for households approaching retirement, but the average for younger households has declined (Munnell, 2012).

One answer to improving retirement plan participation and saving is through education. Many employers have attempted to increase the $401(\mathrm{k})$ participation and saving rate by providing financial education to their employees (International Foundation of Employee Benefit Plans, 2014). However, planning for retirement is complex. In addition to requiring financial knowledge, the decision to contribute to a 401(k) plan entails cognitive effort and necessitates the ability to look beyond a present-day bias (Beshears, Choi, Laibson, \& Madrian, 2009). The ability to resolve complex and future-oriented problems is at times described as critical thinking skills.

Both financial education and critical thinking skills are often part of a four-year college curriculum. This, plus the existence of prior work, have led to two research questions for this study. First, what is the impact of a fouryear college education in preparing young people to start saving early via employer-sponsored 401(k) plans? Second, what is the impact of critical thinking skills on contribution rates to those plans for young, new enrollees?

In this mixed-methods study, we investigated the selected contribution rates to hypothetical 401(k) plans of college-aged individuals about to enter the full-time workforce. We sought to determine what educational factors are related to higher elected contribution rates for those future enrollees. We examined three possible educational influences on a selected contribution rate: enrollment in a finance course during the student's college career, a program of study that provides consistent information on financial analysis and saving, and the student's level of critical thinking skills.

\section{LITERATURE REVIEW}

\section{Financial Literacy}

Much of the literature in the past two decades on financial education and financial behavior has focused on financial literacy. While studies vary in the definition of the term, financial literacy generally refers to the set of knowledge and skills required to manage an individual's financial resources efficiently (Mandell, 2008). Assessment of financial literacy often entails questions on what are considered core financial concepts such as compound interest, real rates of return, and diversification. Financial literacy assessments also often include financial test performance questions, where respondents are asked to make personal financial decisions (Hastings, Madrian, \& Skimmyhorn, 2012; Lusardi \& Mitchell, 2009).

Prior work has found financial literacy to be related to several self-reported financial behaviors. Lusardi and Mitchell (2009) studied data collected from the Rand American Life Panel, an Internet survey of individuals age 18 and older. The researchers used 989 observations from the panel, with an average respondent age of 45 . Sixty percent of respondents were married, $48 \%$ were male, and $29 \%$ had a high school education or less. The authors constructed their own financial literacy index from questions in the survey. In a multivariate analysis, financial literacy was positively related to retirement planning and saving, after controlling for socioeconomic factors. Van Rooij and coauthors (van Rooij, Lusardi, \& Alessie, 2012) added financial literacy questions to an annual survey of households in the Netherlands and analyzed more than 1000 responses. The average respondent's age was just over 50 with over $56 \%$ living with a partner or married and $51.5 \%$ being male. Respondents were divided into quartiles based on their literacy scores. Respondents in the highest quartile had the highest percentage of ownership of stocks, mutual funds, and bonds. Finally, Hilgert and colleagues (Hilgert, Hogarth, \& Beverly, 2003) looked at data from the University of Michigan's monthly phone survey of consumers. The sample included 1,004 respondents from households randomized to represent the U.S. population as whole. The authors found financial literacy to be related to a number of beneficial behaviors, including saving out of each paycheck, diversifying investments, and setting financial goals.

Although financial literacy has been widely studied, questions remain as to whether these types of performance assessments are the best predictive measures for desired financial behaviors. A study of multiple 
financial literacy tests found that the ability to predict financial behaviors, such as planning for retirement, was highly variable and dependent on the specific question asked (Hung, Parker, \& Yoong, 2009). In their literature review, Hastings and colleagues (2012) noted that the causal link between financial literacy and beneficial financial behavior was unclear. There is a possibility that the behavior may increase financial literacy, or that a third factor may positively influence both literacy and financial outcomes. The authors suggested that rather than focusing on measuring financial literacy, research should focus on those measures that when changed produce desired financial behavior.

\section{Financial Education}

One way that educational institutions and companies attempt to increase desired financial behavior is by offering finance courses, financial seminars, or workshops. Individuals whose employers offer financial education tend to have a higher level of financial literacy (Lusardi \& Mitchell, 2009). When retirement planning is available in the workplace, people tend to save more for retirement (Bernheim \& Garrett, 2003). One study of the impact of an eight-hour personal financial management course for new army soldiers found that it positively affected saving rates in the Thrift Savings Plan, a plan for federal employees and members of the uniformed services that is similar to a 401(k) (Skimmyhorn, 2012). However, one-time classes and short-term workshops may not produce the desired financial behavior. To be effective, financial education needs to provide regular reinforcement of a consistent financial message (Bernheim \& Garrett, 2003) and must be extensive, frequent, ongoing, and mandatory (Willis, 2011).

Mandell (2008) suggested that given the rate of change and complexity of today's financial system, being able to research and solve problems are key skills in making personal financial decisions, and that these skills are frequently learned in college. The author reported on the findings of the 2008 National Jump\$tart Coalition Survey of High School Seniors and College Students (Mandell, 2008), which asked financial scenario questions of 6,856 $12^{\text {th }}$ grade students and 1,030 full-time college students. The high school sample was stratified by state, and high schools were randomly selected to be surveyed. The college sample was obtained from a panel maintained by Survey Sampling International (SSI), from which a subset of respondents age 18 to 23 was drawn.

Mandell found that college students scored higher on the financial questions, with $61.9 \%$ answers correct, than high school students, who averaged $48.3 \%$ correct answers. Students in four-year college curriculums scored higher on average $(62.6 \%)$ than students in two-year colleges $(58.7 \%)$. Mandell also found that scores varied by college major. The mean score for arts majors was the lowest reported, at $59.4 \%$, while science and social science majors had the highest mean score of $64 \%$. Business or finance majors scored an average of $62.4 \%$. Scores also differed based on what financially oriented courses students had taken. Students exposed to money management ideas in a portion of some course scored an average of $58.2 \%$ on the questions, while students who had taken a finance course scored $64.6 \%$. Unfortunately, the author provided only descriptive statistics in the categories above, and none of the score differences were analyzed for statistical significance. Given these findings, we wondered: what is the impact of college major and taking a finance course on the elected contribution rates to 401(k) plans of college-age new enrollees?

While the studies above suggest that education affects financial literacy, many researchers still feel that the connections are questionable among financial literacy, financial education, and financial behavior (Hastings, Madrian, \& Skimmyhorn, 2012; Willis, 2011). In their literature review, Hastings and colleagues (2012) noted that even in studies that examined financial behavior, rather than just financial knowledge or literacy, findings were contradictory regarding whether financial education improved financial outcomes. The research reviewed included natural experiments, designed experiments, and self-reported outcomes. The studies using self-reported outcomes tended to find a positive relationship, while findings were mixed in the experimental research. The authors concluded that there was insufficient evidence to determine the settings under which financial education improves financial outcomes. 


\section{Critical Thinking}

The decision of how much to contribute to a $401(\mathrm{k})$ is complex and requires cognitive effort to combine information from multiple sources (Beshears, Choi, Laibson, \& Madrian, 2009). The combination of knowledge and skills involved in complex problem solving, weighing options, considering future scenarios, calculating likelihoods, and making decisions is often referred to as critical thinking (Halpern, 1998; Wolcott, 2005). Critical thinking training is often incorporated into college-level curriculums (Roth, 2010; Kunsch, Schnarr, \& van Tyle, 2014), yet a recent study found that $36 \%$ of students showed no improvement in critical thinking skills after four years of college (Arum \& Roska, 2011). One of the challenges relating to both the teaching and learning of critical thinking is whether such training needs to be context-specific or if it is a general set of skills that can be taught and applied later in varying situations (Behar-Horenstein \& Niu, 2011).

The critical thinking needed to decide how much to save through a 401(k) plan requires consideration of a broad array of factors, both present and future in focus. Enrollees must consider their current financial status, commitments, and goals as well as forecast future needs, both short-term and long-term. In addition, not only must enrollees understand the plan options presented, they must also have knowledge of basic financial concepts, including but not limited to the time value of money, compound interest, and tax laws. To add further to the complexity, for young, new college graduates the decision requires them to plan for a life they have yet to live, with income and choices previously unavailable to them. Research on 401(k) plan participation has shown that the complexity of the decisions involved often causes individuals to put off the decision, adversely affecting their total saving amounts (Beshears, Choi, Laibson, \& Madrian, 2009). Thus, while critical thinking skills may be taught in higher education curriculums, do such skills in general aid in 401(k) decision-making or is additional specifically financial contextual training needed?

We sought to investigate the variables and questions posed above with a group of college-age students who would soon be making their first retirement plan decisions. Much of prior work has focused on older respondents (average age 40 to 50) who have already made retirement plan saving decisions. Once a financial behavior has been enacted, the direction of causality is questionable, as the behavior itself may lead to higher financial literacy or increase critical thinking regarding retirement planning. This study investigated the impact of education before the possible confounding impact of a decision action. In addition, we aimed to better understand the thinking of young decision makers, in order to better determine steps to take to improve financial retirement outcomes for that group.

Additionally, this study builds on Mandell's work on college-age individuals by analyzing differences in retirement planning by academic major and finance education, to determine statistical significance. Finally, the experimental approach used here will help to refine information on what conditions best support beneficial retirement planning financial decisions.

\section{METHOD AND RESULTS}

\section{Method}

We surveyed students in a mid-size university in the Midwest. Three colleges within the university were selected for sampling: business, pharmacy, and communication. This mix of colleges yielded a base of respondents with a variety of majors, backgrounds, and curricular experiences. We were interested in obtaining responses from students who had and had not taken business courses, and who had and had not taken finance courses. The colleges also afforded a large cohort of juniors and seniors, who would soon be making 401(k) plan decisions upon graduation. In the semester of the study, emails were sent to faculty who were teaching classes with more than 20 students, asking if students in their class could be surveyed. A minimum of 20 students in a class was selected in order to minimize the number of classes disrupted by participation and was a natural cutoff between relatively larger and smaller classes in the university. Eight out of nine faculty responded, and nine classrooms were surveyed. All students in all of the nine classes responded to the survey. Students were provided with an informational description of $401(\mathrm{k})$ plans as well as a hypothetical scenario in which they had been hired for a job paying $\$ 50,000$ per year. The students were asked to enroll in the company's 401(k) plan where the employer would match their contribution, up to $3 \%$ of their salary. They were asked to select a percentage contribution rate between $0 \%$ and $15 \%$. The 
scenario provided is shown in Appendix A. In addition, respondents were asked for educational information: whether they had taken a finance course, their major, grade point average, and in what college they were enrolled within the university. Gender and age were also collected.

To capture the critical thinking involved in the decision, respondents were asked to provide a written description of the rationale behind the contribution rate they selected. These descriptions were analyzed independently by each of the three authors and evaluated for evidence of critical thinking skills. Each respondent was assigned a critical thinking score of "1," "2," or "3." Responses that showed heavy present-bias or a lack of considering options, future scenarios, or likelihoods were given a score of "1." Those that showed some consideration of future possibilities or options scored "2," and those that showed evidence of complex thinking, where multiple options and future likelihoods were considered, were scored as "3." Scores from the independent ratings were compared, and where rankings differed, the authors discussed their evaluations to arrive at an agreedupon single score.

Finally, prior work has shown that the default saving contribution rate presented in a 401(k) scenario affects the saving rate selected by new enrollees (Beshears, Choi, Laibson, \& Madrian, 2009). To control for this effect, we varied the suggested saving rate in the scenarios. In half of the surveys, the suggested rate was listed as $3 \%$, which is the rate most frequently cited in employer plans. In the other half of the surveys, a $15 \%$ suggested rate was used. In this way we could examine the impact of financial education and critical thinking in the presence of alternative default rates.

\section{Descriptive Results}

Table 1 contains the summary statistics. A total of 334 students were surveyed. Respondents were enrolled in one of three different colleges in the university. Forty-seven percent were from the pharmacy college, $37 \%$ were from the business college, and 16\% were from the communications college. Forty-one percent of the students were male and 59\% were female. All students were upperclassmen, that is, in their junior or senior year or equivalent. Forty-seven percent of students had taken or were enrolled in a finance course at the time the survey was administered, and 16\% reported finance as their major. The average self-reported grade point average (GPA) was 3.468 , which was identified as being artificially high. This was controlled for in the hierarchical linear modeling analysis described below. The average age of the survey respondent was 21.2 years. Due to lack of variability in age, the variable was dropped from further analysis. Twenty-two percent of the respondents were assigned a critical thinking score of "1," 71\% were assigned a score of "2," and 7\% were assigned a score of "3." The variables in the analysis are listed below. All dummy variables were coded " 1 " for the value listed and "0" for all other values. 
Variable

Dummy Variables

Finance Course

Business College

Finance Major

Male

Auto Enrollment 15

Critical Thinking 1

Critical Thinking 2

Critical Thinking 3
Description respondent had taken (or was currently enrolled in) a finance course respondent's primary field of study was within the college of business respondent was a finance major or minor gender of the respondent the default enrolled contribution rate was $15 \%$ of salary (vs. $3 \%$ ) the respondent was awarded a critical thinking score of "1" the respondent was awarded a critical thinking score of "2" the respondent was awarded a critical thinking score of "3"

\title{
Other Variables \\ $G P A$ \\ Age \\ Elected Rate
}

\author{
the self-reported cumulative grade point average of the respondent \\ the current age of the respondent \\ the respondent's elected contribution rate
}

Table 1 lists descriptive statistics and correlations. The mean for the dummy variables indicates the percentage of responses that fell into that named category. For instance, for the variable Business College, the mean of 0.373 corresponds to $37 \%$ of the responses being from students in that college. There was a high correlation between students who had taken a finance course and students who were enrolled in the college of business (0.840). This is due to a requirement that all business majors or minors must take at least one finance course prior to graduating. The sample purposefully consisted of upperclassmen in order to obtain responses from individuals who would soon be entering the workforce. It is expected that these upperclassmen would have already fulfilled the finance course requirement. Due to the high correlation with Business College, Finance Course was dropped from further analysis.

\section{Analysis and Results}

Hierarchical linear modeling (HLM) was used for the linear regression model testing. This type of analysis is useful when the primary level of analysis (the individual) is nested within a higher level (classroom) (for examples, see Diestel, Wegge, \& Schmidt, 2014; Arthaud-Day, Rode, \& Turnley, 2012). According to Raudenbush and Bryk (2002), HLM multilevel models have improved power and unbiased estimates compared to analysis of the same data with a single-level model. In order to control for variances across classrooms, this research used the individual and classroom as the two levels in an HLM analysis.

Table 1. Descriptive Statistics and Correlations

\begin{tabular}{|c|c|c|c|c|c|c|c|c|c|c|}
\hline Variable & Mean & s.d. & 1 & 2 & 3 & 4 & 5 & 6 & 7 & 8 \\
\hline Elected Rate & 0.082 & 0.038 & & & & & & & & \\
\hline Finance Course & 0.466 & 0.500 & $.216^{* *}$ & & & & & & & \\
\hline Business College & 0.373 & 0.484 & $.241 * *$ & $.826 * *$ & & & & & & \\
\hline Finance Major & 0.157 & 0.365 & $.130 *$ & $.463 * *$ & $.560 * *$ & & & & & \\
\hline Age & 21.201 & 1.671 & -.091 & $.114^{*}$ & .022 & -.021 & & & & \\
\hline Male & 0.410 & 0.493 & .094 & $.434 * *$ & $.427 * *$ & $.394 * *$ & .061 & & & \\
\hline GPA & 3.468 & 0.339 & $.126^{*}$ & $-.136^{*}$ & -.097 & -.078 & $-.186 * *$ & $-.237 * *$ & & \\
\hline Auto-Enrollment 15 & 0.475 & 0.500 & $.250 * *$ & .040 & .032 & .030 & -.026 & .092 & -.042 & \\
\hline Critical Thinking 1 & 0.220 & 0.416 & $-.201 * *$ & -.008 & .002 & -.048 & .047 & -.072 & $-.121 *$ & $.130^{*}$ \\
\hline Critical Thinking 2 & 0.710 & 0.456 & $.116^{*}$ & -.078 & -.077 & -.001 & $-.142 *$ & .004 & .100 & $-.120 *$ \\
\hline Critical Thinking 3 & 0.070 & 0.257 & $.120 *$ & $.151 * *$ & $.134 *$ & .079 & $.176^{* *}$ & $.110^{*}$ & .018 & .002 \\
\hline
\end{tabular}

*significant at $\mathrm{p}<0.05 ; * *$ significant at $\mathrm{p}<0.01$ 
Table 2. HLM Model Results

\begin{tabular}{lcc}
\hline \multicolumn{1}{c}{ Variable } & Coefficient & Std.Error \\
\hline Intercept & 0.070 & 0.003 \\
GPA & $0.016^{*}$ & 0.006 \\
Auto Enrollment 15 & $0.021^{* * *}$ & 0.004 \\
Business College & $0.020^{* * *}$ & 0.005 \\
Finance Major & -0.002 & 0.007 \\
Male & -0.002 & 0.005 \\
Critical Thinking 1 & $-0.020^{* * *}$ & 0.005 \\
Critical Thinking 3 & 0.008 & 0.008 \\
Individual Level & 0.200 & \\
$\quad$ Pseudo R-Squared & & \\
Group Level & 0.310 & \\
$\quad$ Pseudo R-Squared & &
\end{tabular}

When using multilevel models, Luke (2004) suggests running a null model to determine if there is enough between-classroom variance to justify using such a model. In our null model, Elected Rate was used as the dependent variable, with no predictor variables. The null model equation was:

$$
\text { ElectedRate }_{\mathrm{ij}}=\gamma_{00}+\mathrm{u}_{0 \mathrm{j}}+\mathrm{r}_{\mathrm{ij}}(1)
$$

Where $\gamma_{00}$ is the random intercept at level $2, \mathrm{u}_{0 \mathrm{j}}$ is the random error associated with the intercept and $\mathrm{r}_{\mathrm{ij}}$ the level 1 residual error term. The intra-class coefficient of the null model was $6 \%$. The chi-squared test indicated that the between-group variance was significantly different from zero ( $p$-value $<0.001$ ), suggesting that multilevel modeling is appropriate for these data.

The final model tested was:

ElectedRate $_{i j}=\gamma_{00}+\gamma_{10} * G P A_{i j}+\gamma_{20} *$ AutoEnrollment $15_{i j}+\gamma_{30} *$ BusinessCollege $_{i j}+\gamma_{40} *$ FinanceMajor $_{i j}$

$+\gamma_{50} *$ CriticalThinking $1_{i j}+\gamma_{60} *$ CriticalThinking $3_{i j}+\gamma_{70} *$ Male $_{i j}+u_{0 j}+r_{i j}$

As noted earlier, it was determined that the self-reported GPAs of respondents were artificially high. To control for reporting bias, and as suggested by Raudenbush and Bryk (2002), GPA was group-centered in the model.

The results of the model are shown in Table 2. Model fit in multilevel modeling is assessed at each level through the change in deviance (-2 log likelihood) and change in residual variance. The change in deviance is interpreted similarly to a traditional $\mathrm{R}^{2}$ and is called the pseudo- $\mathrm{R}^{2}$ (Snijders \& Bosker, 1994). The pseudo- $\mathrm{R}^{2}$ at the individual level was $21 \%$ and at the group level was $31 \%$.

The model suggests that being enrolled in the college of business and GPA are positively related to a higher elected contribution rate. We also found that respondents who were assigned a critical thinking score of "1" elected a lower contribution rate than students who were assigned a score of "2." Being assigned the highest critical thinking score of " 3 " was not related to a higher in the elected contribution rate, as compared to students who were assigned a score of "2." Respondents for whom the higher default rate was used in the plan scenario (15\%, Auto Enrollment 15) elected a higher contribution rate than respondents for whom the default was 3\%. Gender and being a finance major were not related to elected contribution rate, after controlling for the other factors.

\section{DISCUSSION}

Our findings on college enrolled (business) and finance major build on Mandell's (2008) work, by testing the statistical significance of the impact of different majors on financial knowledge and decisions. Students in the college of business elected higher contribution rates for $401(\mathrm{k})$ plans than students with other academic majors. We suggest that this is due to exposure within the business curriculum to a financial message that is consistent, frequent, and ongoing. In a college of business, students take a wide variety of courses, including accounting, economics, and 
business analytics courses, in which they are asked to analyze and make decisions using financial data. This set of coursework typically occurs over several years. In the university studied, these courses are required for business majors. Our research found that students whose majors do not require these financial and business-decision-making courses elected overall lower contribution rates. This finding supports earlier work suggesting that decision makers need financial education that is regular, extensive, and mandatory (Bernheim \& Garrett, 2003; Willis, 2011) in order to make informed, long-term financial decisions.

However, being a finance major did not make a statistically significant difference in the elected contribution rate, when controlling for college curriculum. This differs somewhat from Mandell, who found that students who had taken a finance course scored higher on a financial literacy test $(64.7 \%)$ than students who had only been exposed to money management ideas in a course (58.3\%). Therefore, we ran an additional model without the business college variable. We found that Finance Major was significant $(\mathrm{r}=0.013, \mathrm{p}<0.05)$ when the model did not control for college, supporting the differences found by Mandell.

We also found that critical thinking plays an important role in making 401(k) saving decisions. Students who showed the ability to get beyond a present-bias, to think about future scenarios and likelihood, and to combine multiple factors in their decision-making elected higher contribution rates. This effect was independent of a student's major. Behar-Horenstein and Niu (2011) raised the question as to whether critical thinking teaching and learning needs to be context-specific. Our finding suggests that such skills are transferrable to a different context. In this study, non-business students were able to apply the general critical thinking skills they had learned to a situation that was likely new to them, specifically deciding on a 401(k) saving rate. In addition, for both business and nonbusiness students, overall GPA was positively related to higher elected contribution rates.

These results extend earlier work on financial literacy and its impact on saving and setting financial goals. As noted earlier, some have questioned the causal link between financial literacy and beneficial financial behaviors (ex. Hung, Parker, \& Yoong, 2009; Hastings, Madrian, \& Skimmyhorn, 2012). The potential reverse causality issue was addressed by sampling young, potential new enrollees. The students surveyed have not yet participated in retirement planning, so the learning acquired by that financial behavior could not have affected their financial knowledge or critical thinking skills. In addition, we found that college major, and critical thinking affect financial behaviors and those factors may affect financial literacy itself. More work is required to further investigate the latter relationship.

If a goal of future education is to encourage higher rates of saving among young retirement plan enrollees, the findings from this study suggest several possible areas of action. The first opportunity is to include more financially related information and messages within the non-business curriculum. This type of information needs to be spread over an extended period of time and in different contexts. Such education should be mandatory so that all individuals receive the same information. For educational institutions, this would require adding financial decisionmaking problems to a broader base of core courses such as math or analytical reasoning classes, and perhaps adding required personal finance courses to curriculums. Preferably this would begin in high school to ensure the broadest reach to young people. For companies looking to add financial education to their employee training programs, these findings suggest that it must be mandatory and conveyed repeatedly in a variety of settings.

A second opportunity is to incorporate the development of critical thinking skills further into a variety of courses. The ability to think beyond the present state, consider multiple options, and make informed choices would not only benefit individuals' future financial decisions, but would have a bearing on decisions in all realms of their lives. For students, early and repeated exposure to building critical thinking skills would also likely assist them in their coursework and result in higher GPAs as well. For employees, development of critical thinking skills is likely to reap rewards on both an individual and organizational level.

Other areas in academe that could assist with this type of education might be career or internship services. As those areas have close ties to future employers, workshops, speakers, and other events could include information on financial decision-making that students will have to make immediately upon graduation. Workshops could be targeted for each year in a four-year curriculum and students could earn badges for learning real world financial skills. Career and academic advisors could help students look beyond courses just in their major, encouraging them 
to take additional classes relating to financial decision-making and critical thinking skills in different contexts. Internship services could also work with employers to devise work assignments incorporating financial and analytical skills that would boost students' general critical thinking abilities. More research is needed in this area to determine how institutions of higher learning can best educate students on the financial skills needed.

\section{LIMITATIONS}

This study was conducted in one mid-size university, with students who majored in three different curriculums. Additional studies from other educational institutions are needed to further support the findings here regarding the impact of curriculums and GPA. In addition, it would be useful to study young people not currently enrolled in post-secondary education in order to better understand the role of critical thinking skills in 401(k) plan contribution rates. The findings here are also limited in that the choices made by students were based on a scenario and not real-world choices in their first jobs. Students may make different choices when they have been hired and are making the actual $401(\mathrm{k})$ contribution decision. However, testing the actual elected rates of new, young employees would require collecting data from one firm across time or collecting data from a variety of firms. In both cases, numerous other variables would be introduced that would be difficult to control for, including varying plan designs, economic conditions, and participant characteristics.

\section{CONCLUSION}

Today's educators and students alike continually face the question of what set of courses and skills will best prepare students for the future. This study suggests that development of critical thinking skills and repeated exposure to analysis of financial data would increase 401(k) saving rates and thereby benefit all students in terms of their future financial well-being. Outside of the academic realm, the results suggest that companies that provide financial-planning education to their employees on a continuous basis will be more effective in increasing the elected 401(k) saving rate, helping to enhance employee financial well-being. Many companies either are including or are planning to include financial education as a line item in their budget (International Foundation of Employee Benefit Plans, 2014). Our study is a step in helping to provide input into what type of education to provide future students and 401(k) enrollees.

The findings here suggest several areas for future study. As noted earlier, research is needed to further uncover the relationships among financial literacy, college major, and critical thinking skills. In what way, if any, do those factors and others influence financial literacy? Our study compared three colleges: business, pharmacy, and communication. How would students fare who represent different colleges and majors, such as basic science or more math-based studies? Also, research is needed on the cross-curriculum approach suggested in the Discussion section above. If there are universities that currently use this approach, how is it being implemented and what has been the impact on students' financial behaviors? Finally, a longitudinal study that surveys students again a year after graduation would best answer the question about how education influenced financial behavior. In making their actual decision about the elected contribution rate, what was the rate they chose and why?

\section{AUTHOR INFORMATION}

Priscilla A. Arling is an Associate Professor in the College of Business, Butler University. She holds a Ph.D. in Information and Decision Sciences from the Carlson School of Management, University of Minnesota, and an M.B.A. from the University of Missouri-Kansas City. Priscilla's research interests include student performance, social network analysis, communication, and health care management. (Contact author)

Jill Kirby is an Assistant Professor in the College of Business, Butler University. She holds a Ph.D. in Finance and an M.S. in Economics from the Gatton College of Business and Economics, University of Kentucky. She worked for 17 years as an actuary and is a member of the Casualty Actuarial Society. Jill's research interests include market anomalies and barriers to arbitrage as well as retirement planning.

Kegan Saajasto, at the time of this research, was a senior honors student majoring in Finance and Information Systems in the College of Business, Butler University. 


\section{REFERENCES}

American Benefits Council. (2013). Trends in 401(k) Plans and Retirement Rewards. Retrieved November, 12,2014 from http://www.americanbenefitscouncil.org/documents2013/abc-waw-surveytrendsin401kplans-2013.pdf.

Arthaud-Day, M. L., Rode, J. C., \& Turnley, W. H. (2012). Direct and Contextual Effects of Individual Values on Organizational Citizenship Behavior in Teams. Journal of Applied Psychology, 97(4), 792-807.

Arum, R., \& Roksa, J. (2011). Academically adrift: Limited learning on college campuses. Chicago: University of Chicago Press.

Behar-Horenstein, L. S., \& Niu, L. (2011). Teaching critical thinking skills in higher education: A review of the literature. Journal of College Teaching \& Learning, 8(2), 25-42.

Bernheim, B. D., \& Garrett, D. M. (2003). The Effects of Financial Education in the Workplace: Evidence from a Survey of Households. Journal of Public Economics, 87(7-8), 1487-1519.

Beshears, J., Choi, J. J., Laibson, D., \& Madrian, B. C. (2009). The Importance of Default Options for Retirement Saving Outcomes: Evidence from the United States. In Social Security Policy in a Changing Environment (pp. 167-195). Chicago: University of Chicago Press.

Clark, K. (2013, March 7). Save Money. That's an Order. Interview with Mier Statman. Money Magazine. Retrieved October 2, 2014 from http://time.com/money/2792316/save-money-thats-an-order/.

Diestel, S., Wegge, J., \& Schmidt, K. (2014). The Impact of Social Context on the Relationships between Individual Job Satisfaction and Absenteeism: The Roles of Different Foci of Job Satisfaction and Work-Unit Absenteeism. Academy of Management Journal, 57(2), 353-382.

Halpern, D. F. (1998). Teaching Critical Thinking for Transfer Across Domains: Disposition, skills, structure training, and metacognitive monitoring. American Psychologist, 53(4), 449-455.

Hastings, J. S., Madrian, B. C., \& Skimmyhorn, W. L. (2012). Financial Literacy, Financial Education and Economic Outcomes (NBER Working Paper No. 18412). Cambridge, MA: National Bureau of Economic Research.

Hilgert, M. A., Hogarth, J. M., \& Beverly, S. G. (2003). Household Financial Management: The Connection between Knowledge and Behavior. Federal Reserve Bulletin, 89, 309-322.

Hung, A., Parker, A. M., \& Yoong, J. (2009). Defining and Measuring Financial Literacy, (RAND Working Paper WR708). Santa Monica, CA: RAND Corporation.

International Foundation of Employee Benefit Plans. (2014). Financial Education for Today's Workforce: 2014 Survey Results Preliminary Summary of Findings. Retrieved November 3, 2014 from https://www.ifebp.org/bookstore/financialeducation/Pages/default.aspx.

Kunsch, D. W., Schnarr, K., \& van Tyle, R. (2014). The Use of Argument Mapping to Enhance Critical Thinking Skills in Business Education. Journal of Education for Business, 89(8), 403-410.

Luke, D. A. (2004). Multilevel Modeling. Thousand Oaks, CA: Sage Publications.

Lusardi, A., \& Mitchell, O. S. (2009). How Ordinary Consumers Make Complex Economic Decisions: Financial Literacy and Retirement Readiness. National Bureau of Economic

Research. Retrieved November 3, 2014 from http://www.nber.org/papers/w15350.pdf.

Lusardi, A., Mitchell, O. S., and Curto, V. (2010). Financial Literacy Among the Young. Journal of Consumer Affairs, 44(2), 358-380.

Mandell, L. (2008). The Financial Literacy of Young American Adults. Retrieved [date] from http://www.jumpstart.org/assets/files/2008SurveyBook.pdf.

Munnell, A. H. (2012). 401(k) Plans in 2010: An Update from the SCF. Center for Retirement Research at Boston College. Retrieved [date] from http://crr.bc.edu/wp-content/uploads/2012/07/IB 12-13-508.pdf.

Raudenbush, S. W., \& Bryk, A. S. (2002). Hierarchical Linear Models: Applications and Data Analysis Methods, Thousand Oaks, CA: Sage Publications.

Roth, M. S. (2010). Beyond critical thinking. The Chronicle of Higher Education, January 3, 2010.

Skimmyhorn, W. (2012). Essays in Behavioral Household Finance (Doctoral dissertation). Harvard University Kennedy School, Cambridge, MA.

Snijders, T., \& Bosker, R. (1994). Modeled Variance in Two-Level Models. Sociological Methods \& Research, 22(3), 343-363.

van Rooij, M. C. J., Lusardi, A., \& Alessie, R. J. M. (2012). Financial Literacy, Retirement Planning and Household Wealth. Economic Journal, 122(560), 449-478.

Willis, L. E. (2011). The Financial Education Fallacy. The American Economic Review, 101(3), 429-434.

Wolcott, S. K. (2005). Assessment of Critical Thinking. In K. Martell \& T. Calderon (Eds.), Assessment of Student Learning in Business Schools: Best Practices Each Step of the Way (pp. 130-153). Tallahasee, FL: Association for Institutional Research. 


\section{APPENDIX A}

\section{Survey Scenario}

Assume that you get a post graduate position with a company paying you $\$ 50,000$ per year. The company will match up to $3 \%$ of the contribution to the $401 \mathrm{k}$ plan. Initially, you are automatically enrolled at a $15 \% *$ contribution rate. Remember the more you save the more you will have at retirement, but the less current income you will have to spend.

For Example: If you save $0 \%$, you could purchase a new Toyota Corolla in the first year out of college and live in a one bedroom apartment with no roommates in your desired neighborhood.

If you save 15\%, you could purchase a used Toyota Corolla with 75,000 miles and live in an apartment with 2 roommates in a less desirable neighborhood.

When I graduate, I would elect to change the percentage contribution rate to $15 \%)$ . (Enter one number from 0 to

Please briefly describe your reasoning behind your answer.

*Half of surveys listed a default rate of $15 \%$ and the other half listed a default rate of $3 \%$. 
NOTES 